\title{
Effects of Long-Term Use of Flavonoids on the Absorption and Tissue Distribution of Orally Administered Doses of Trace Elements in Rats
}

\author{
Ausama Ayoob Jaccob ${ }^{1}$, Saad Abdulrahman Hussain ${ }^{2 *}$ \\ ${ }^{1}$ Department of Pharmacology and Toxicology, College of Pharmacy, Al-Basra University, Basra, Iraq; ${ }^{2}$ Department of Pharma- \\ cology and Toxicology, College of Pharmacy, University of Baghdad, Baghdad, Iraq. \\ Email: "saad_alzaidi@yahoo.com
}

Received July 26 ${ }^{\text {th }}, 2012$; revised August $28^{\text {th }}$, 2012; accepted September $12^{\text {th }}, 2012$

\begin{abstract}
The risk of pharmacokinetic polyphenols-trace elements interaction may undesirable therapeutic outcomes. We evaluate the long-term use of silibinin, epigallocatechin (ECGC), quercetin and rutin on the absorption and tissue distribution of zinc, copper and iron after single oral doses in rats. Five groups of rats received either with olive oil as control or one of the polyphenols silibinin, EPGC, quercetin or rutin, administered orally as oily solutions for 30 days. At day 30, a solution contains sulphate salt of zinc, copper and iron was administered orally; 3 hrs later blood samples, tissues of brain, kidney and liver were obtained for evaluation of the elements levels. The results showed that the polyphenols increased both serum and tissue levels of these elements compared with controls. This effect was relatively varied according to the structural differences among flavonoids. In conclusion, long-term use of supraphysiological doses of flavonoids increase absorption of $\mathrm{Zn}, \mathrm{Cu}$ and $\mathrm{Fe}$ and their tissue availability in brain, kidney and liver; this effect seems to be different with variations in structural features.
\end{abstract}

Keywords: Flavonoids; Trace Elements; Absorption; Tissue Distribution

\section{Introduction}

Flavonoids (polyphenolic compounds) are one of the bioactive compounds widely available in fruits and vegetables [1]. Flavonoids have long been associated with a variety of biochemical and pharmacological properties, including antioxidant, antiviral, anticarcinogenic, and anti-inflammatory activities [2], and believed to be beneficial to human health. Many peoples are motivated by scientific research that is widely carried in the news media, which indicated these flavonoids and polyphenols could prevent cancer, ageing, and cardiovascular diseases [3,4]. However, these researches are often carried out in animals and their effects in humans remain uncertain [5]. A large body of evidence, mainly derived from preclinical studies in animals, has concluded that dietary polyphenols, when given in large quantities, can have desirable outcomes [6]. There is currently an extensive range of flavonoid supplements on the market [7]. Suppliers of such supplements recommend daily flavonoid intakes in amounts that are many times higher than those doses which can normally be achieved from a flavonoid-rich diet. The question arises whether supplements containing such supra-physio-

\footnotetext{
"Corresponding author.
}

logical flavonoid levels may exhibit adverse effects. In addition, it is likely that a large proportion of individuals taking dietary flavonoid supplements are also taking conventional drugs or trace elements [8]. The concomitant intake of "supra-nutritional" flavonoid doses together with conventional drugs may lead to flavonoid-drug interactions [8]. Approximately 38 million adults in the US (18.9\% of the population) use herbal products that contain flavonoids or other natural supplements, but only one third tell their physician about this use [9]. This lack of information, combined with the fact that natural products are usually a mixture of many active ingredients, increases the likelihood of harm. Moreover, this additionally raises concerns about the safe use of dietary flavonoids. The risk of pharmacokinetic polyphenols-trace elements interaction poses two major extremity challenges, pharmacotoxicity and treatment failure. The former can result from the inhibition of the homeostatic mechanisms responsible for the absorption, tissue distribution and clearance of the trace elements, while the latter may be the consequence of inducing processes the lead to faster clearance. This is in addition to the intrinsic pharmacodynamic actions of the polyphenols themselves which may include potentiating, additive, antagonism, or neu- 
tralization effects. The present study was designed to evaluate the effect of long-term use of supraphysiological doses of silibinin, epigallocatechin gallate, quercetin and rutin on the absorption and tissue distribution of orally administered doses of the trace elements zinc copper and iron in rats.

\section{Materials and Methods}

\subsection{Chemicals and Reagents}

Silibinin dihemisuccinate (SDH) (98\% purity) was obtained from Tolbiac SRL, Argentina; Quercetin dihydrate (98\% pure standardized extract) was purchased from Xian Co, China; Epigallocatechin gallate (EGCG) was a gift from Al-Razi Pharm Ind, Syria; Rutin was obtained from Merck Laboratories, Germany; Ferrous sulphate, Copper sulphate and Zinc sulphate were obtained from SD Fine Chemicals, India.

\subsection{Animals and Study Design}

Thirty male adult Sprague Dawly rats of body weight 200 - 250 g were obtained from the Animal House, Department of Pharmacology and Toxicology, College of Pharmacy, Baghdad University, and the experiments were carried out in Department of Pharmacology, College of Pharmacy, Al-Basra University, Iraq. The rats were housed under controlled conditions $\left(22^{\circ} \mathrm{C}-25^{\circ} \mathrm{C}\right)$ on a 12 $\mathrm{h}$ light/12 h dark cycle, and received the standard pellet diet (National Center for Drug Research and Quality Control, Baghdad) and water ad libitum. The study protocol was approved by the Institutional Animal Ethical Committee (IAEC), College of Pharmacy, University of Baghdad. After acclimatization for a period of one week, the animals were allocated into five groups consisting of 6 rats each; first group was treated with vehicle (olive oil) as control group; the other four groups are treated with one of the flavonoids: SDH (100 mg/kg), EGCG (25 $\mathrm{mg} / \mathrm{kg}$ ); Quercetin (50 mg/kg) and Rutin (500 mg/kg). All flavonoids are prepared as oily solutions dissolved in olive oil and introduced as single daily doses administered orally using gavage tube for 30 consecutive days; the control group receives $0.2 \mathrm{~mL} /$ day of olive oil in the same way. At day 30, all groups of rats received orally single doses of Zinc sulphate (60 mg/kg), Copper sulphate (60 mg/kg) and Fe sulphate (60 mg/kg), all these elements were administered 2 hrs after administration of the last doses of the flavonoids and the vehicle.

\subsection{Samples Preparation}

After 3.0 hrs of administration of trace metals, all animals are sacrificed after short duration anesthesia with anesthetic ether; blood samples were drawn and collected in polyethylene tube, centrifuged at $10000 \mathrm{rpm}$ for 20 min and the resulted serum was kept frozen at $-20^{\circ} \mathrm{C}$ until trace elements analysis. The liver and both kidneys were quickly removed and perfused with ice-cooled saline; the brain was carefully excised, rinsed with icecooled saline and the arachnoid membrane was carefully removed. One gram tissue of the obtained organs and 1.0 $\mathrm{ml}$ of serum were digested utilizing the wet digestion method [10,11]; the digested samples were stored in refrigerator and used later for analysis of tissue and serum levels of zinc, copper and iron [12].

\subsection{Analysis of Trace Elements}

The contents of $\mathrm{Zn}, \mathrm{Cu}$ and $\mathrm{Fe}$ in serum and tissue samples were first released from the protein matrix by wet digestion method as mentioned previously, and their concentrations were determined using atomic absorption spectrophotometer (Buck Scientific, Model 211-VGI, USA) at wavelength of $214 \mathrm{~nm}$ for zinc, $247 \mathrm{~nm}$ for Fe and 324 for $\mathrm{Cu}$ [13]. Standard solutions of these elements were used to prepare calibration carve for quantitative analysis.

\subsection{Statistical Analysis}

Values were expressed as mean \pm S.D; the values were statistically evaluated using unpaired Student's t-test and one way analysis of variance (ANOVA), supported by Bonferroni's post hoc analysis. Values with $P<0.05$ were considered significantly different. Analysis was performed using GraphPad Prism software for Windows (version 5.0, GraphPad Software, Inc., San Diego, CA).

\section{Results}

Figure 1 showed that all the flavonoids used in the present study significantly increased $(P<0.05)$ the GI absorption of $\mathrm{Zn}$, when administered as single oral dose compared to control group; meanwhile, no significant differences in serum $\mathrm{Zn}$ levels were reported among the effect of the four flavonoids $(P>0.05)$ in this respect. Concerning long-term effects of the tested flavonoids on the absorption of $\mathrm{Cu}$, all of them produced significant increase $(P<0.05)$ in serum $\mathrm{Cu}$ levels compared to the values reported in controls; only SDH and quercetin demonstrated significantly different effects in this respect (lower effect for quercetin), when the effects of the four flavonoids compared with each others (Figure 2). In Figure 3, treatment of rats with one of the four flavonoids used in the study for 30 days resulted in significant increase $(P<0.05)$ in the oral absorption of $\mathrm{Fe}$ when administered as single dose of ferrous sulphate compared to control group. When the effects of the studied flavon- 
oids were compared, non-significant differences were reported between the effects of SDH and quercetin, while the others showed significant differences in the order: EGCG $>$ SDH $=$ quercetin $>$ rutin (Figure 3).

The effects of flavonoids on the organ availability and percent amounts of $\mathrm{Zn}, \mathrm{Cu}$ and Fe distributed to the brain, kidneys and liver relative to serum levels were evaluated after administration of single oral doses of those elements. In Table 1, the results showed that all administered flavonoids significantly increased the tissue availability

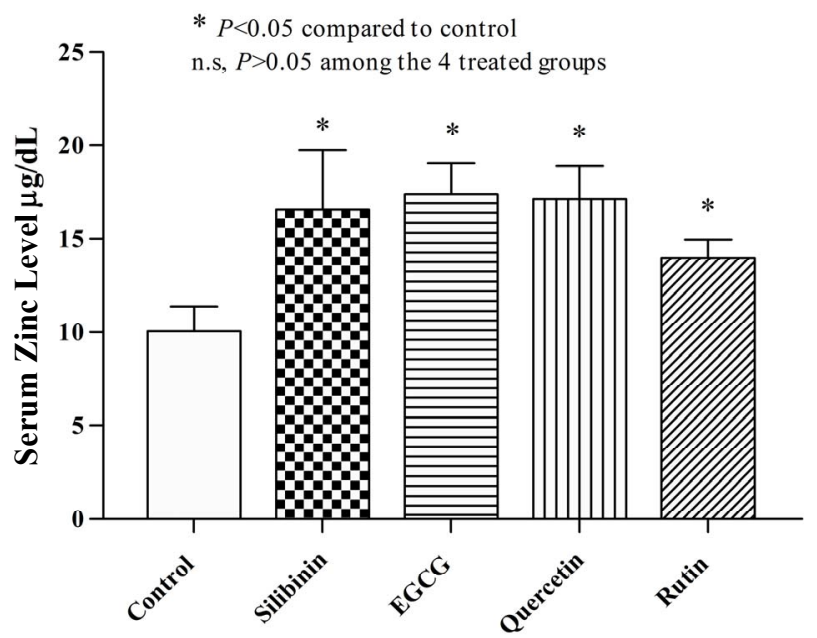

Figure 1. Effects of long-term administration of silibinin $(100 \mathrm{mg} / \mathrm{kg})$, EGCG $(25 \mathrm{mg} / \mathrm{kg})$, quercetin $(50 \mathrm{mg} / \mathrm{kg})$ and rutin $(500 \mathrm{mg} / \mathrm{kg})$ on serum levels of $\mathrm{Zn}$ in rats after single oral dose of this element.

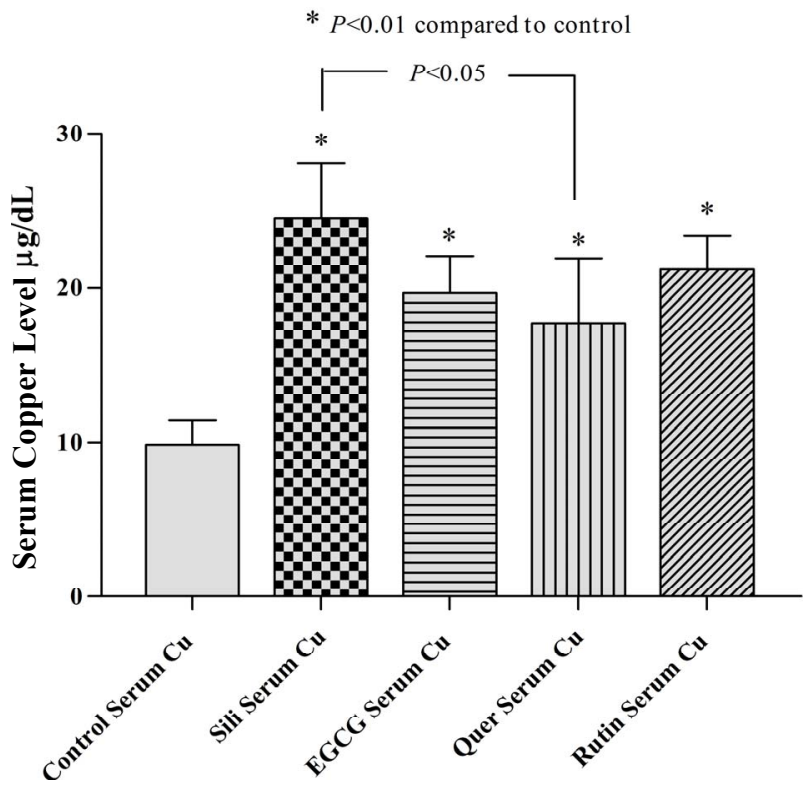

Figure 2. Effects of long-term administration of silibinin $(100 \mathrm{mg} / \mathrm{kg})$, EGCG $(25 \mathrm{mg} / \mathrm{kg})$, quercetin $(50 \mathrm{mg} / \mathrm{kg})$ and rutin $(500 \mathrm{mg} / \mathrm{kg})$ on serum levels of $\mathrm{Cu}$ in rats after single oral doses of this element. of the essential metals ( $\mathrm{Zn}, \mathrm{Cu}$ and $\mathrm{Fe}$ ) compared to the value reported in control group. The most prominent effect for the studied flavonoids in this respect was reported on iron tissue availability, where EGCG produced consistent increase in the three targeted organs while rutin showed the lowest effect in this respect compared to others. Concerning the effects on the tissue availability of $\mathrm{Zn}$ and $\mathrm{Cu}$, the influence is relatively comparable for all flavonoids in all organs (especially for $\mathrm{Cu}$ ) and EGCG demonstrates the lowest effect on $\mathrm{Zn}$ availability in the three organs. In Figure 4, the influence of the flavonoids on percent $\mathrm{Zn}$ availability in the brain tissue relative to serum levels indicated comparable effects,

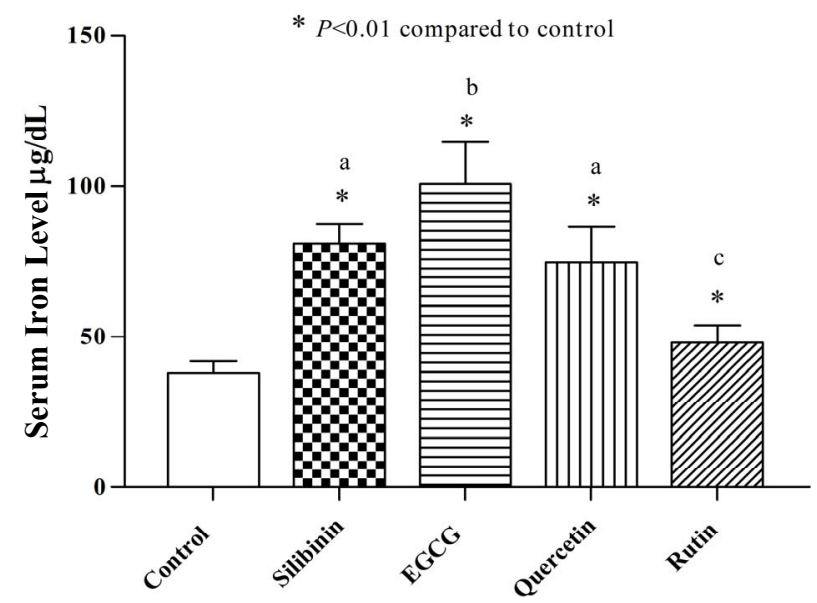

Figure 3. Effects of long-term administration of silibinin $(100 \mathrm{mg} / \mathrm{kg})$, EGCG $(25 \mathrm{mg} / \mathrm{kg})$, quercetin $(50 \mathrm{mg} / \mathrm{kg})$ and rutin $(500 \mathrm{mg} / \mathrm{kg})$ on serum levels of $\mathrm{Fe}$ in rats after single oral dose of this element.

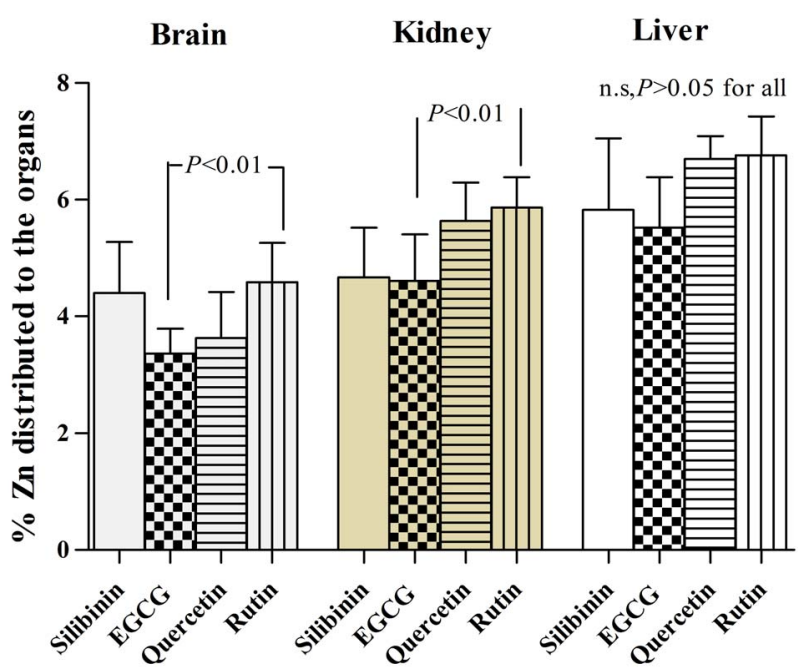

Figure 4. Effects of long-term administration of silibinin $(100 \mathrm{mg} / \mathrm{kg})$, EGCG $(25 \mathrm{mg} / \mathrm{kg})$, quercetin $(50 \mathrm{mg} / \mathrm{kg})$ and rutin $(500 \mathrm{mg} / \mathrm{kg})$ on tissue availability of $\mathrm{Zn}$ in Brain, Kidneys and Liver relative to serum levels in rats after single oral dose of this metal. 
Table 1. Effects of long-term administration of silibinin $(100 \mathrm{mg} / \mathrm{kg})$, EGCG $(25 \mathrm{mg} / \mathrm{kg})$, quercetin $(50 \mathrm{mg} / \mathrm{kg}) \mathrm{and} \mathrm{rutin}(500$ $\mathrm{mg} / \mathrm{kg}$ ) on tissue availability of $\mathrm{Zn}, \mathrm{Cu}$ and $\mathrm{Fe}$ in Brain, Kidneys and Liver of rats after single oral doses of these metals.

\begin{tabular}{|c|c|c|c|c|c|c|c|c|c|}
\hline \multirow{3}{*}{$\begin{array}{l}\text { Treatment } \\
\text { groups }\end{array}$} & \multicolumn{9}{|c|}{ Tissue Levels of Trace Elements $\mu \mathrm{g} / \mathrm{g}$ Tissue } \\
\hline & \multicolumn{3}{|c|}{ Zn } & \multicolumn{3}{|c|}{$\mathrm{Cu}$} & \multicolumn{3}{|c|}{$\mathrm{Fe}$} \\
\hline & Brain & Kidney & Liver & Brain & Kidney & Liver & Brain & Kidney & Liver \\
\hline Control & $32.9 \pm 2.1$ & $35.6 \pm 3.1$ & $44.8 \pm 5.7$ & $34.2 \pm 3.7$ & $39.4 \pm 5.5$ & $47.6 \pm 4.2$ & $23.2 \pm 5.7$ & $205.2 \pm 27.8$ & $318.3 \pm 34.2$ \\
\hline Silibinin & $70.8 \pm 4.9^{* a}$ & $75.3 \pm 6.0^{* a}$ & $94.0 \pm 12.2^{* a}$ & $63.5 \pm 4.6^{* a}$ & $72.0 \pm 2.6^{* a}$ & $85.6 \pm 3.7^{* a}$ & $64.8 \pm 12.1^{* \mathrm{a}}$ & $456.8 \pm 53.0^{* a}$ & $738.9 \pm 90.3^{* a}$ \\
\hline EGCG & $58.4 \pm 6.3^{* b}$ & $79.3 \pm 6.6^{* a}$ & $95.4 \pm 9.7^{* a}$ & $60.3 \pm 4.3^{* b}$ & $75.6 \pm 7.6^{*_{a}}$ & $84.3 \pm 9.6^{* a}$ & $71.2 \pm 9.1^{* a}$ & $727.3 \pm 81.4^{* \mathrm{~b}}$ & $954.6 \pm 125.4^{* b}$ \\
\hline Quercetin & $61.0 \pm 7.5^{* b}$ & $95.7 \pm 9.0^{* \mathrm{~b}}$ & $114.6 \pm 10.7^{* \mathrm{~b}}$ & $67.3 \pm 7.0^{* \mathrm{~b}}$ & $70.0 \pm 4.7^{* a}$ & $80.0 \pm 5.7^{* a}$ & $67.3 \pm 7.0^{* a}$ & $579.3 \pm 111.0^{*_{c}}$ & $634.8 \pm 67.4^{* a}$ \\
\hline Rutin & $63.7 \pm 6.4^{* \mathrm{~b}}$ & $81.7 \pm 2.8^{* a}$ & $94.2 \pm 5.4^{* a}$ & $68.3 \pm 9.1^{* \mathrm{~b}}$ & $74.6 \pm 11.1^{* a}$ & $80.6 \pm 12.5^{* a}$ & $42.5 \pm 3.2^{* b}$ & $352.6 \pm 46.7^{* d}$ & $461 \pm 34.4^{* \mathrm{c}}$ \\
\hline
\end{tabular}

Values are presented as mean \pm S.D; $\mathrm{n}=6$ animals in each group, ${ }^{*}$ significantly different compared to control group $(P<0.05)$; values with non-identical superscripts (a, b, c, d) for the same metal in the same organ are considered significantly different $(P<0.05)$.

with exception of a significant difference between the effect of EGCG and rutin (rutin > EGCG); the same pattern of activity was reported regarding the distribution of Zn in kidney tissues. Moreover, Figure 4 indicated that all the tested flavonoids produced comparable effects $(P>0.05)$ on the tissue availability of $\mathrm{Zn}$ in the liver relative to serum level after single oral dose of Zinc sulphate. Figure 5 sowed that the effects of the flavonoids on percent $\mathrm{Cu}$ distribution to the brain tissue relative to serum levels were comparable, with exception of a significant difference between the effect of silibinin and quercetin (Quercetin > SDH); the same pattern of activity was reported regarding the distribution of $\mathrm{Cu}$ in kidney tissues.

Additionally, Figure 5 indicated that all the tested flavonoids produced comparable effects $(P>0.05)$ on the liver tissue availability of $\mathrm{Cu}$ relative to serum level after single oral dose of Copper sulphate. Concerning the influence of the tested flavonoids on tissue availability of Fe after single oral dose of ferrous sulphate, Figure 6 indicated that no significant differences were reported regarding their effects on brain and liver tissues availability of Iron. Meanwhile, significant differences were reported between the effects of silibinin compared with those produced by quercetin and rutin respectively (Quercetin > SDH and rutin > SDH); the effect of EGCG in this respect was found non-significantly different compared with the other three flavonoids used in the study.

\section{Discussion}

High consumption of flavonoids rich diet may potentiate other deleterious effects of drugs or trace elements because of their diverse pharmacological properties; moreover, it may modulate drugs activity and the activities of environmental toxins and metalloenzymes. Thus, although there is evidence that a flavonoid-rich diet or supplements may promote good health and provide

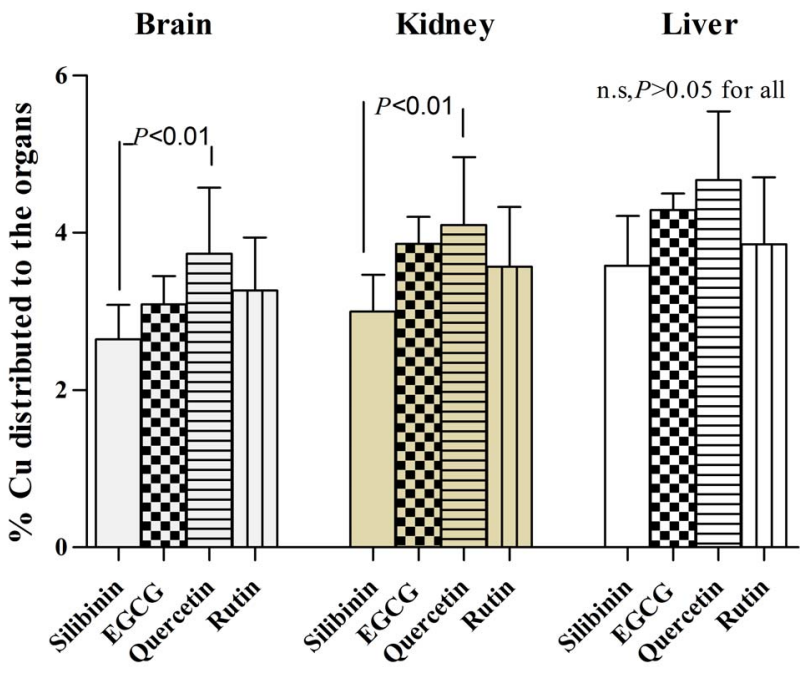

Figure 5. Effects of long-term administration of silibinin $(100 \mathrm{mg} / \mathrm{kg})$, EGCG $(25 \mathrm{mg} / \mathrm{kg})$, quercetin $(50 \mathrm{mg} / \mathrm{kg})$ and rutin $(500 \mathrm{mg} / \mathrm{kg})$ on tissue availability of $\mathrm{Cu}$ in Brain, Kidneys and Liver relative to serum levels in rats after single oral dose of this metal.

protection from many diseases, the conditions and the levels of flavonoid intake that may pose a potential hazard remains to be determined. Globally, dietary intake of mixed flavonoids is estimated to be in the range of 500 - $1000 \mathrm{mg}$, but it can be as high as several grams in those persons supplementing their diets with flavonoids or flavonoid-containing herbal preparations such as ginko biloba or grape seed extract [14]. These high doses may lead to pharmacological concentrations in body fluids and tissues. In the present study, orally administered doses of SDH, EGCG, quercetin and rutin to rats for 30 days, significantly improved both serum levels and tissue availability of orally administered doses of the essential elements, $\mathrm{Zn}, \mathrm{Cu}$ and $\mathrm{Fe}$ compared control animals. The explanation of such finding seems to be a little bit difficult, since conflicting reports are available 


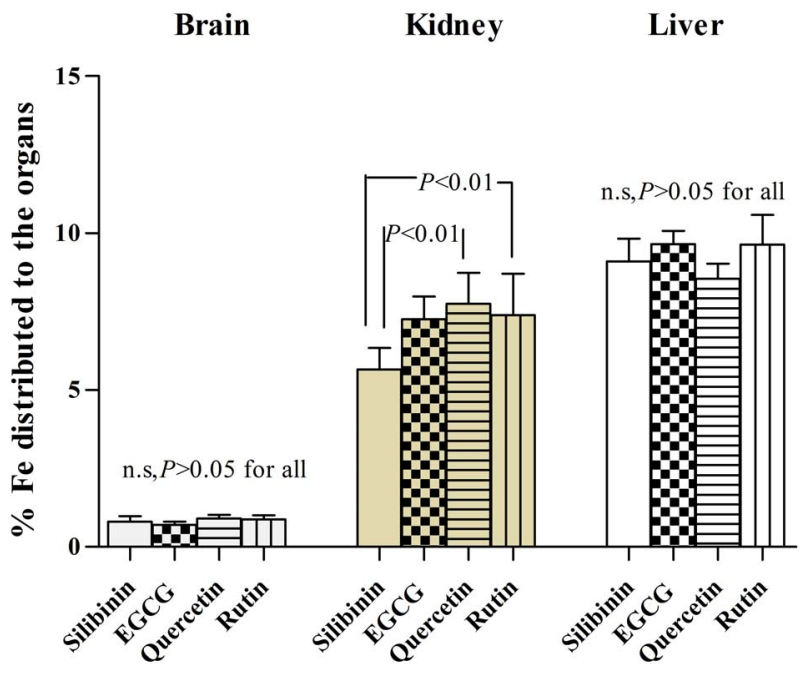

Figure 6. Effects of long-term administration of silibinin $(100 \mathrm{mg} / \mathrm{kg})$, EGCG $(25 \mathrm{mg} / \mathrm{kg})$, quercetin $(50 \mathrm{mg} / \mathrm{kg})$ and rutin $(500 \mathrm{mg} / \mathrm{kg})$ on tissue availability of $\mathrm{Fe}$ in Brain, Kidneys and Liver relative to serum levels in rats after single oral dose of this metal.

regarding the influence of polyphenols intake on trace elements homeostasis. Flavonoids can act as transition metal ion chelators $[15,16]$. This feature plays an important role in their antioxidant activity because the free radical generation is mainly catalyzed by transition metals in vivo and in vitro. However, excessive intake of flavonoids may cause a decrease in essential trace elements ( $\mathrm{Cu}$ and $\mathrm{Zn})$ and their related enzyme activities. According to many previously reported data, flavonoids as transition metal chelators, when used in excessive amounts may cause a decrease of trace minerals, such as iron, copper, and zinc [17]. In contrast to this idea, we have shown in this study that with oral administration of supraphysiological doses of SDH, EGCG, quercetin and rutin, the availability of iron, copper, and zinc levels in the serum and tissues after single oral doses of these elements was increased compared to controls. In the present study, the higher serum and tissue availability of the essential elements can be explained according to the fact that absorption and membrane transport of some metals ions were enhanced when they form complexs and chelates with organic ligands. In tune with this finding, many data were reported on metal binding to proteins in the cells $[18,19]$ and the higher availability of chelated elements may be linked to the shielding of the minerals positive charge during chelation. This allows the mineral to withstand the binding activity of the negatively charged mucin layer and results in lower competition between minerals of similar charge in their resorption from the gut and transfer to the enterocyte. These phenomena, combined with lower complex formation in the intestinal lumen with compounds such as phytate, may contribute to the higher absorption of minerals from the gut. Moreover, feeding trials in mammalian species have shown that complexes of organic compounds with trace minerals have higher relative bioavailability than inorganic ones and provide alternative pathways for absorption, thus leading to a reduction in the excretion of minerals [20-22]. Another possible explanation for this behavior is based on the metal chelating ability of polyphenols, which is related to the presence of ortho-dihydroxy polyphenol, i.e., molecules bearing catechol or galloyl groups and condensed tannins; the possibility of occurrence of chelation in physiological $\mathrm{pH}$ also supports the physiological significance of this phenomenon [23]. In tune with our finding, in an in vitro study, polyphenol-rich beverages such as red wine, red grape juice, and green tea or certain specific polyphenols (tannic acid and quercetin) have the ability to enhance the uptake of zinc in Caco-2 cells [24]. Luminal interactions with ligands have drastic consequences for the bioavailability of metals. Some metal complexes are very stable. Depending on the lipophilicity, such a complex may be absorbed, distributed and possibly excreted without releasing its metal moiety. Thus, in spite of sufficient absorption, the metal may not be metabolically available. Although the available information suggests that polyphenolic compounds can chelate many essential elements ( $\mathrm{Zn}, \mathrm{Cu}$ and $\mathrm{Fe}$ ) and may affect their availability for absorption [25], Coudray et al. (2000) reported that shortor long-term consumption of polyphenols present in wine did not have a negative effect on intestinal absorption or tissue levels of zinc and $\mathrm{Cu}$ in rats [26]; the results of the present study are found relatively comparable with this finding, even when supraphysiological doses of polyphenols were introduced in pure form, and for the first time showed some differences between certain flavonoids in this respect. The differences between flavonoids reported in the present study could be related to the differences in certain structural properties, including the number and distribution of hydroxyl groups at specific parts of the structural formula; this will consequently affect the physicochemical properties of these flavonoids, especially lipid solubility and interactions with biological targets. Meanwhile, the interaction between dietary flavonoids and trace minerals may affect metal homeostasis in a structure-specific fashion. Since fluid properties of biological membranes were essential for numerous cell functions including solute transport and membraneassociated enzymatic activities [27], it is possible that even mild alterations produced by the lipophilic structures of flavonoids on membrane fluidity could cause aberrant function and changes in membrane permeability [28]. The D-ring hydroxyl groups of the flavonoid structure occupy the first coordination sphere around metal ion to form a diolate combination ring, while B-ring 
hydroxyl groups have weak interactions with metal ions [29]. As suggested by previous reports [30,31], the number of hydroxyl groups on the B-ring in many flavonoids structures, the presence of a galloyl moiety, and the steric characters on the D-ring could affect its affinity for the lipid bilayers. As a result of this, incorporation of the flavonoids into the lipid bilayers was enhanced, which could lead to the formation of another ion channels after complexing of flavonoids with metal ions, which is expected to induce structural variation and influence the effects of structurally different flavonoids in this respect. In conclusion, long-term use of supraphysiological doses of flavonoids increase gastrointestinal absorption of essential elements ( $\mathrm{Zn}, \mathrm{Cu}$ and $\mathrm{Fe}$ ) and their tissue availability in brain, kidney and liver; this effect seems to be different with variations in structural features of the flavonoids.

\section{Acknowledgements}

The presented data was abstracted from $\mathrm{PhD}$ thesis submitted to the Department of Pharmacology and Toxicology, College of Pharmacy, University of Baghdad. The authors thank University of Baghdad for supporting the project.

\section{REFERENCES}

[1] S. Pascual-Teresa, D. A. Moreno and C. Garcia-Viguera, "Flavanols and Anthocyanins in Cardiovascular Health: A Review of Current Evidence,” International Journal Molecular Sciences, Vol. 11, No. 4, 2010, pp. 1679-1703. doi:10.3390/ijms11041679

[2] E. Middleton, C. Kandaswami and T. C. Theoharides, "The Effects of Plant Flavonoids on Mammalian Cells: Implications for Inflammation, Heart Disease and Cancer,” Pharmacological Reviews, Vol. 52, No. 4, 2000, pp. 673-751.

[3] V. M. Adhami and H. Mukhtar, "Polyphenols from Green Tea and Pomegranate for Prevention of Prostate Cancer," Free Radicals Research, Vol. 40, No. 10, 2006, pp. 10951104. doi:10.1080/10715760600796498

[4] H. E. Seifried, D. E. Anderson, E. I. Fisher and J. A. Milner, "A Review of the Interaction among Dietary Antioxidants and Reactive Oxygen Species,” Journal of $\mathrm{Nu}$ trition and Biochemistry, Vol. 18, No. 9, 2007, pp. 567579. doi:10.1016/j.jnutbio.2006.10.007

[5] B. Halliwell, "Dietary Polyphenols: Good, Bad, or Indifferent for Your Health?” Cardiovascular Research, Vol. 73, No. 2, 2007, pp. 341-347. doi:10.1016/j.cardiores.2006.10.004.

[6] S. C. Thomasset, D. P. Berry, G. Garcea, T. Marczylo, W. P. Steward and A. J. Gescher, "Dietary Polyphenolic Phytochemicals-Promising Cancer Chemopreventive Agents in Humans? A Review of Their Clinical Properties,” International Journal of Cancer, Vol. 120, No. 3, 2007, pp.
451-458. doi:10.1002/ijc.22419

[7] J. C. Espin, M. T. Garcia-Conesa and F. A. Tomas-Barberan, "Nutraceuticals: Facts and Fiction," Phytochemistry, Vol. 68, No. 22-24, 2007, pp. 2986-3008. doi:10.1016/j.phytochem.2007.09.014

[8] R. Cermak, "Effect of Dietary Flavonoids on Pathways Involved in Drug Metabolism," Expert Opinion in Drug Metabolism and Toxicology, Vol. 4, No. 1, 2008, pp. 17-35. doi:10.1517/17425255.4.1.17doi:10.1093/ecam/nem045

[9] J. Kennedy, C. C. Wang and C. H. Wu, "Patient Disclosure about Herb and Supplement Use among Adults in the US,” Evidence Based Complement Alternative Medicine, Vol. 5, No. 4, 2008, pp. 451-456.

[10] O. O. Babalola, R. E. Okonji, J. O. Atoyebi, T. F. Sennuga, et al., "Distribution of Lead in Selected Organs and Tissues of Albino Rats Exposed to Acute Lead Toxicity," Scientific Research Essay, Vol. 5, No. 9, 2010, pp. 845848.

[11] R. A. Jacob, H. H. Sandstead, J. M. Munoz, L. M. Klevay and D. B. Milne, "Whole Body Surface Loss of Trace Metals in Normal Males," American Journal of Clinical Nutrition, Vol. 34, No. 7, 1981, pp. 1379-1383.

[12] Z. Gao, H. Xu and K. Huang, "Effects of Rutin Supplementation on Antioxidant Status and Iron, Copper and Zinc Contents in Mouse Liver and Brain,” Biological Trace Elements Research, Vol. 88, No. 3, 2002, pp. 271279. doi:10.1385/BTER:88:3:271

[13] O. Akinloye, F. M. Abbiyesuku, O. O. Oguntibeju, A. O. Arowojolu and E. J. Truter, "The Impact of Blood and Seminal Plasma Zinc and Copper Concentrations on Spermogram and Hormonal Changes in Infertile Nigerian Men,” Reproductive Biology, Vol. 11, No. 2, 2011, pp. 83-98.

[14] C. F. Skibola and M. T. Smith, "Potential Health Impacts of Excessive Flavonoid Intake," Free Radicals in Biology and Medicine, Vol. 29, No. 3, 2000, pp. 375-383. doi:10.1016/S0891-5849(00)00304-X

[15] I. Morel, G. Lescoat, P. Cognel, O. Sergent, N. Pasdelop, P. Brissot, et al., "Antioxidants and Iron-Iron-Chelating Activities of the Flavonoids Catechin, Quercetin and Diosmetin on Iron-Loaded Rat Hepatocyte Cultures,” Biochemical Pharmacology, Vol. 45, No. 1, 1993, pp. 13-19. doi:10.1016/0006-2952(93)90371-3

[16] P. Sestili, A. Guidarelli, M. Dacha and O. Cantoni, "Quercetin Prevents DNA Single Strand Breakage and Cytotoxicity Caused by Tert-Butylhydroperoxide: Free Radical Scavenging Versus Iron Chelating Mechanism,” Free Radicals in Biology and Medicine, Vol. 25, No. 2, 1998, pp. 196-200. doi:10.1016/S0891-5849(98)00040-9

[17] S. Samman, B. Sandstrom, M. B. Toft, K. Bukhave, M. Jensen, S. S. Sorensen and M. Hansen, "Green Tea or Rosemary Extract Added to Foods Reduces NonhemeIron Absorption,” American Journal of Clinical Nutrition, Vol. 73, No. 3, 2001, pp. 607-612.

[18] M. Murariu, E. S. Dragan and G. Drochioiu, "Electrospray Ionization Mass Spectrometric Approach of Conformationally-Induced Metal Binding to Oligopeptides," European Journal of Mass Spectrometry, Vol. 16, No. 4, 
2010, pp. 511-521. doi:10.1255/ejms.1092

[19] G. Drochioiu, M. Manea, M. Dragusanu, M. Murariu, et al., "Interaction of Beta-amyloid(1-40) peptide with Pairs of Metal Ions: An Electrospray Ion Trap Mass Spectrometric Model Study,” Biophysical Chemistry, Vol. 144, No. 1-2, 2009, pp. 9-20. doi:10.1016/j.bpc.2009.05.008

[20] Y. M. Bao, M. Choct, P. A. Iji and K. Bruerton, "Effect of Organically Complexed Copper, Iron, Manganese and Zinc on Broiler Performance, Mineralexcretion and Accumulation in Tissues," Journal of Applied Poultry Research, Vol. 16, No. 3, 2007, pp. 448-455.

[21] L. Nollet, J. D. van der Klis, M. Lensing and P. Spring, "The Effect of Replacing Inorganic with Organic Trace Minerals in Broiler Diets on Productive Performance and Mineral Excretion,” Journal of Applied Poultry Research, Vol. 16, No. 4, 2007, pp. 592-597. doi:10.3382/japr.2006-00115

[22] A. G. Abdallah, O. M. El-Husseiny and K. O. Abdel-Latif, "Influence of Some Dietary Organic Mineral Supplementations on Broiler Performance," International Journal of Poultry Sciences, Vol. 8, No. 3, 2009, pp. 291-298. doi:10.3923/ijps.2009.291.298

[23] M. Andjelkovic, J. van Camp, B. de Meulenaer, G. Depaemelaere, et al., "Iron-Chelation Properties of Phenolic Acids Bearing Catechol and Galloyl Groups," Food Chemistry, Vol. 98, No. 1, 2006, pp. 23-31. doi:10.1016/j.foodchem.2005.05.044

[24] K. Sreenivasulu, P. Raghu and K. M. Nair, "PolyphenolRich Beverages Enhance Zinc Uptake and Metal-Lothionein Expression in Caco-2 Cells,” Journal of Food Sciences, Vol. 75, No. 4, 2010, pp. H123-H128. doi:10.1111/j.1750-3841.2010.01582.x.

[25] C. Coudray, C. Bousset, D. Pepin, J. C. Tressol, et al.,
"Short-Term Ingestion of Chlorogenic or Caffeic Acids Decreases Zinc But not Copper Absorption in Rats, Utilization of Stable Isotopes and Inductively Coupled Plasma Mass Spectrometry Technique,” British Journal of Nutrition, Vol. 80, No. 6, 1998, pp. 575-584.

[26] C. Coudray, J. C. Tressol, C. Feillet-Coudray, J. Bellanger, et al., "Long-Term Consumption of Red Wine Does Not Modify Intestinal Absorption or Status of Zinc and Copper in Rats,” Journal of Nutrition, Vol. 130, No. 5, 2000, pp. 1309-1313.

[27] D. G. Salinas, M. de La Fuente and J. G. Reyes, “Changes of Enzyme Activity in Lipid Signaling Pathways Related to Substrate Reordering,” Biophysics Journal, Vol. 89, No. 2, 2005, pp. 885-894. doi:10.1529/biophysj.104.057307

[28] N. T. de Gomez Dumm, A. M. Giammona, L. A. Touceda and C. Raimondi, "Lipid Abnormalities in Chronic Renal Failure Patients Undergoing Hemodialysis,” Medicina (B Aires), Vol. 61, No. 2, 2001, pp. 142-146.

[29] R. E. Navarro, H. Santacruz and M. Inoue, "Complexation of Epigallocatechin Gallate (a Green Tea Extract, EGCG) with $\mathrm{Mn}^{2+}$ : Nuclear Spin Relaxation by the Paramagnetic Ion,” Journal of Inorganic Biochemistry, Vol. 99, No. 2, 2005, pp. 584-588. doi:10.1016/j.jinorgbio.2004.11.013

[30] T. Hashimoto, S. Kumazawa, F. Nanjo, Y. Hara and T. Nakayama, "Interaction of Tea Catechins with Lipid Bilayers Investigated with Liposome Systems,” Bioscience Biotechnology and Biochemistry, Vol. 63, No. 12, 1999, pp. 2252-2255. doi:10.1271/bbb.63.2252

[31] K. Kajiya, S. Kumazawa and T. Nakayama, "Steric EfFects on Interaction of Tea Catechins with Lipid Bilayers," Bioscience Biotechnology and Biochemistry, Vol. 65, No. 12, 2001, pp. 2638-2643. doi:10.1271/bbb.65.2638. 